\title{
Running out of juice
}

\section{Despite the hype, there's no sign that the Congress will produce an energy bill worthy of the formidable energy-policy challenges faced by the United States.}

S uppose that one was charged with the task of framing US energy legislation from scratch, without the political baggage that has accumulated over several years' unsuccessful efforts to push such a law through the Congress.

One top priority, endorsed at both ends of the political spectrum, would undoubtedly be to reduce the United States' large and growing reliance on imported oil. Another - which unfortunately benefits from no such political consensus - would be to stabilize and then to reduce the nation's greenhouse-gas emissions. A third priority would be to support a balanced programme of energyrelated research and development at a level commensurate with the massive scale of the US energy business, not to mention its longterm strategic importance.

A range of options for tackling these pressing concerns were spelt out robustly last year in the final report of the independently funded, bipartisan National Commission on Energy Policy (see www.energycommission.org).

But judging from the version of the bill passed by the House

"The bill obstinately declines to take seriously

the need to cut carbon emissions." of Representatives last month none of these concerns are being properly addressed by the Congress. For a start, the bill obstinately declines to take seriously the need to cut carbon emissions. It does nothing to contain the demand for oil through the most obvious mechanism, the imposition of modest fuel-efficiency standards for cars and light trucks. And it fails to authorize any substantial revival in energy research spending, which has been steadily run down from its peak in the aftermath of the 1974 energy crisis.

The Senate is this week releasing a measure that will purport to look at the bigger picture. A bipartisan bill being put forward jointly by Senator Pete Domenici (Republican, New Mexico) and Jeff Bingaman (Democrat, New Mexico) will take a more broadly based approach than the House bill, and boost spending on some aspects of energy research.

But even the Senate seems to lack the will to seriously confront the consequences of the US addiction to oil imports. The bill will provide generous subsidies for clean coal and nuclear-power generation, and less generous ones for renewable energy sources. But in a country where about two-thirds of energy use is for transportation, it seems unlikely to bite the bullet and take steps to reduce oil consumption. The Senate could start to address this by, for example, promoting new cellulose-based biofuels (not to be confused with the existing ethanol programme, which is designed primarily as a subsidy machine for corn farmers). It could also yet decide to insist on new fuel-efficiency standards.

But many leaders in the Congress seem to prefer to squabble over oil drilling in the Arctic National Wildlife Refuge in Alaska, rather than address the issue of oil consumption. The impression continues to grow that the president and congressional leaders want to win on the Alaskan refuge primarily to rile environmentalists, rather than to obtain oil. Oil companies are barely registering an interest, the political and economic costs being so high.

As is usual for legislation of this type, the House bill is laden with goodies for special interests, including some $\$ 2$ billion for deep gas drilling, subsidies for those keen to build nuclear power stations, and various tax breaks. But even the corporate giveaways - which are valued by some critics at $\$ 8$ billion over ten years - are paltry by Washington's standards of profligacy. This is further proof, if any were needed, that political leaders just haven't grasped the scale of the problem.

\section{Iran's long march}

\section{Scientific excellence can re-emerge in Iran, unless there is political upheaval or further sanctions.}

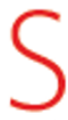
tories about people who prevail against the odds are always heart-warming, and the tale in this issue of Nature about a group of Iranian neuroscientists (see page 264) is no exception. Such successes have been rare in Iran's recent history. Over the past few years, however, the country has been investing more public money in science, and nurturing the gradual emergence of a climate in which high-quality research can flourish.

During this period, social and political constraints on Iranian life have visibly relaxed. Headscarves on the streets of Tehran are now sometimes perched so far back that Velcro is needed to stop them falling off altogether. Science has also benefited from this relaxation.

Even Ayatollah Ali Khamenei, the senior cleric effectively in charge of the country, has been speaking up for science, calling on his country to develop "self-confidence in all scientific fields". The call resonates within a small academic community that is keenly aware of Iran's rich and ancient heritage of scientific achievement.

The government, led by the elected president, Mohammad Khatami, has meanwhile increased science funding. It has also introduced reforms - approved this year, after a tough fight - that give universities and research institutes much more autonomy. In February, academics' salaries were sharply increased: as a result, many of them will be able to make ends meet without a second job, for the first time since the Islamic revolution in 1979.

Some of the most productive laboratories, such as the Institute for 
Studies in Theoretical Physics and Mathematics (IPM) in Tehran and the Institute for Advanced Studies in Basic Sciences (IASBS) in Zanjan, have taken the opportunity presented by the reform package to reorganize themselves. The IPM says it is basing its new structure on that of the Max Planck Society in Germany, in which the research directors of individual labs have full control over budgets and research agendas.

The publication rate of Iranian scientists in international journals, meanwhile, has quadrupled over the past decade. Although still relatively low, the average impact factor of Iranian papers has also risen. But much of the improvement can be traced back to a small number of researchers. The number of papers per researcher at the IASBS, for example, is nearly twice that of its closest competitor, the Sharif University of Technology in Tehran. The reforms set out to extend the base of scientific excellence in Iran.

That may prove difficult to accomplish, given the current isolation of Iranian scientists from their peers abroad. US economic sanctions make it difficult for them to travel to meetings in the United States. And because most scientific equipment contains US components that are covered by sanctions, Iranians can only procure it through middle-men who disguise the equipment's ultimate destination but inflate its price and leave recipients with no quality guarantees or maintenance arrangements. Scientists in Iran tell stories of waiting up to two years for an order, only to receive shipment of the wrong model.

Unfortunately, given current tensions over Iran's nuclear programme (see Nature 435,$132 ; 2005$ ), the sanctions are unlikely to be lifted in the short term. Instead, the situation could rapidly deteriorate. Internal support for scientific development and for the free exchange of ideas is far from assured.

The president will be replaced after elections due on 17 June. One candidate for the presidency is immunologist Mostafa Moin, a former research minister who resigned from the government in 2003 in protest at parliamentary opposition to the university reform act. Moin could be relied on to continue along the reformist path set by Khatami. It is just as likely, however, that the elections will yield instead a president less interested in either reform or scientific freedom.

The Iranian scientists who have put together strong research groups have done so by carefully steering clear of politics. But they are admirably determined to help build up a research infrastructure in the country that will outlast their own careers. Scientists everywhere should avail themselves of every opportunity to assist these grassroots efforts.

\section{Policing integrity}

Plagiarism allegations should serve as reminders that universities cannot police misconduct on their own.

S? erious scientific misconduct is a pernicious and under-reported problem that the research community has sought to police, with mixed success. There is little evidence, fortunately, that the falsification or fabrication of research data is becoming more frequent. However, there are rumblings that one type of misconduct is on the increase: plagiarism, made easier by the rapid electronic dissemination of research results (see page 258).

In many countries, the investigation of plagiarism and other misconduct remains fraught with difficulty. Universities are terrified of the adverse publicity that will accompany any finding of misconduct. And if the accused doesn't accept the outcome, they have the option of taking legal action against the accusers, the investigators or the institution in question.

In those circumstances, it is inevitable - although still unfortunate - that some senior university officials will opt for the easiest path, rather than the most righteous one. In some cases, an errant academic may be encouraged to leave an institution without full public disclosure of the events leading to the departure - a lamentable outcome that will simply serve to export misconduct, rather than to deter it.

In the United States, some defences are in place against this kind of thing. Biomedical research is overseen by the Office of Research Integrity (ORI) at the health department; research supported by the National Science Foundation, which funds most non-biomedical university research, is overseen by the Inspector General's office at the foundation. The ORI, in particular, has been active in helping universities run their own investigations properly. And if internal university probes fall short, these bodies can step in and carry out the investigation themselves.

The system established in the United States has never been quite as rigorous or effective as its architects had hoped. Yet the existence of these oversight organizations still puts the United States in a better position to police misconduct than most other nations.

In Britain, the universities themselves, through a group called Universities UK, are developing plans to establish a central office to oversee biomedical research. But the plans have already run into criticism for failing to let the body pursue its own investigations, and for the odd suggestion by the universities that the office accept sponsorship from the pharmaceutical industry (see Nature 434, 263; 2005).

The major French research agencies have committees for dealing with misconduct, but "It is inevitable -
although still unfortunate
- that some senior
university officials will
opt for the easiest path,
rather than the most
righteous one." none of them are as visible, well staffed or effective as their US counterparts, and Italy has no such arrangement at all. Germany has three full-time ombudsmen on hand to supervise university investigations. The German system was put in place after a prominent case of data fabrication in 1997, when it emerged that dozens of studies by Friedhelm Herrmann and Marion Brach, cancer researchers at the Max Delbrück Centre for Molecular Medicine in Berlin, contained falsified data.

It shouldn't take a recurrence of something like the Herrmann and Brach case for other leading scientific nations to ensure that they have adequate measures in place to investigate misconduct, properly publicize the findings, and punish the culprits. 